\title{
ESTIMATION OF EMOTIONAL AND SOCIAL LONELINESS IN ELDERS WITH THE DEVELOPED ARTIFICIAL NEURAL NETWORKS AND MULTIPLE LINEAR REGRESSION MODELS
}

*Esma UZUNHISARLIKCI, Electronics And Automation/ Kayseri University/ Turkey, uzunhise@erciyes.edu.tr (iDhttps://orcid.org/0000-0003-2821-4177)

Hanife AKGÜL, Educational Science/ Faculty of Education, Çanakkale Onsekiz Mart University/ Turkey, hanifeakgul@comu.edu.tr (Dhttps://orcid.org/0000-0001-8543-9343)

Erhan KAVUNCUOĞLU, Department Of Computer Technologies/Gemerek Vocational School, Cumhuriyet University/ Turkey, ekavuncuoglu@cumhuriyet.edu.tr

(iD https://orcid.org/0000-0001-6862-2891)

Received: 26.07.2019, Accepted: 16.03.2020

*Corresponding author

\section{Abstract}

In recent years, with the increase in the amount of data, the development of the technology required for the analysis of this data has made it easier for artificial intelligence to enter all areas. In this study, "Loneliness Scale for the Elderly" was used to measure loneliness level as a dependent variable, and the predictability of emotional and social loneliness parameters obtained was investigated with artificial intelligence and statistical techniques. For this reason, various scales were used to examine Emotional Loneliness (EL), and Social Loneliness (SL) and various input parameters were used in the scales. In this study, we designed an expert system which uses the Artificial Neural Network (ANN) - Machine Learning Algorithm and Multiple Linear Regression (MLR) statistical methods to estimate the SL and EL values by feeding with input values. Root Mean Squared Error (RMSE) and Correlation Coefficient ( $R$ ) parameters were used to evaluate the predictive performance of the expert system. When the performance criteria were analyzed, it was found that ANN was the best predictor of SL and EL values. Social or emotional loneliness of individuals can be estimated by entering the questionnaire responses that are not included in the sample through the expert system developed in this study.

Keywords: Machine Learning Algorithm, Artificial Neural Network, Multiple Linear Regression, Social Loneliness,

Emotional Loneliness, Expert System

\section{GELİŞMIŞ YAPAY SİNİR AĞLARI VE ÇOKLU DOĞRUSAL REGRESYON MODELLERIYYLE YAŞLILARDA DUYGUSAL VE SOSYAL YALNIZLIK TAHMINII}

\section{Özet}

Son yıllarda, veri miktarının artması ile birlikte bu verinin analizi için gerekli teknolojinin gelişmesi yapay zekanın her alana girişini kolaylaştırmıştır. Bu çalışmada, bağımlı değiş̧ken olan yalnızlık düzeyini ölçmek için "Yaşlılar Iç̧in Yalnızlık Ölçeği" kullanılmış ve elde edilen duygusal ve sosyal yalnızlık parametrelerinin tahmin edilebilirliği yapay zeka ve istatistiksel teknikler araştırılmıștır. Bu nedenle, Duygusal Yalnızlık (EL) ve Sosyal Yalnızlık (SL)'ı incelemek için "YIYÖ” Yaşlılar İçin Yalnızlık Ölçeği'nden elde edilen veriler kullanılmıștır. Çalışmada, girdi değerleri ile beslenerek SL ve EL değerlerini tahmin eden, Yapay Sinir Ağları (ANN) - Makine Öğrenme Algoritması ve Çoklu Linee Regresyon (MLR) İstatistiksel Yöntemlerini kullanan bir uzman sistem tasarlanmıştır. Sistemin, tahmin etme performansını değerlendirmek için Kök ortalama karesel hata (RMSE) ve Korelasyon Katsayısı (R) parametreleri kullanılmıştır. Performans kriterleri analiz edildiğinde SL ve EL değerlerini en iyi tahmin eden modelin ANN olduğu görülmüştür. Bu çalıșmada geliştirilen uzman sistem aracılığı ile örneklem içerisinde bulunmayan anket cevaplarının uzman sisteme girişi yapılarak kişilerin sosyal veya duygusal yalnızlığı tahmin edilebilecektir.

Anahtar Kelimeler: Makine Öğrenme Algoritması, Yapay Sinir Ağı, Çoklu Doğrusal Regresyon, Sosyal Yalnızlık, Duygusal Yalnızlık, Uzman sistem

Cite

Uzunhisarlikcığlu, E., Akgül H., Kavuncuoğlu E.,(2020). “Estimation Of Emotional And Social Loneliness In Elders With The Developed Artificial Neural Networks And Multiple Linear Regression Models", Mugla Journal of Science and Technology, $6(1), 50-62$. 


\section{Introduction}

The feeling of loneliness, specific to a human being, is an emotion which is experienced sometimes or always by every person in any period of their lives. When this feeling and situation is examined and evaluated regarding elders, it is a worldwide social problem since it can be seen in every undeveloped, developing, and developed the country. In recent years, the status of having loneliness for elders has increased as a result of the effects of modernization on the society and the lives of the individuals.

"Loneliness is the most painful one of all human experiences that arises when the need for closeness is not met" [1]. The most commonly used definition of loneliness was made by Peplau and Perlman [2], and they defined loneliness as "an unpleasant emotional state arising as a result of the qualitative and quantitative difference between the existing relations and the desired relations of a person with other people." Loneliness is a negative and subjective experience [3]. According to Geçtan [4], loneliness is a frightening, scary, anxious emotional state which drives individuals to despair, creates tension in them, makes the individual's life meaningless, causes them to create a closed personality, to be a pessimist and to alienate and prevents their socialization. Weiss [5] defined loneliness as an inexplicable subjective phenomenon and mentioned about two distinct forms of loneliness including emotional and social loneliness. Emotional loneliness is the lack of close emotional attachments of the individual. In other words, it is the absence of intimate relationship and an attachment figure of a individual with another individual. Social loneliness is the loneliness resulting from the lack of acceptable social network, joining a social network or the integration of the society. It is a type of loneliness that occurs when an individual has no social network. Emotional loneliness is a response to the lack of a certain direction of a relationship, and this lack cannot be eliminated only by the existence of another relationship [6].

Human life is usually divided into four periods: childhood, youth, adulthood and old age [7]. Old age is one of life stages, just like other periods, but old age is the last stage before the end of the human life and the last step of the development stage. Neugarten and the World Health Organization chronologically divide the old age into three phases [8, 9]: 65-74 years; early old age period, 75-84 years; middle old age period, 85 age and older; very old age. Old age period is seen as a period when there is retardation in physical capacity, fall in biological capacity, a gradual decline in individual skills rather than improvement, an accelerating decline in social and individual expectation levels, along with the increased flexibility in social roles and life $[10,11]$. Along with the enhanced welfare, the share of the elderly population in the total population has gradually increased especially in the developed countries. Also, the average age and life expectancy of society have increased due to the reasons like technological developments, medical developments, welfare spreading to the social base, and increased social opportunities. 313 million of 694 million people aged sixty years and over live in developing countries worldwide. By the year of 2025, it is predicted that this number rise to 840 million. Therefore, almost all of the developed countries witness the aging of their population over the next decades. While one out of every seven people in developed countries today is over the age of 65, one out of every four people is predicted to be in this group in 2030. By the end of 2030, it is predicted that the number of those in the category "old olds (very old)" aged 85 years and over will be six times higher than the number of "young olds" aged 65 years. Over the next 30 years, an increase of up to $300 \%$ is expected in the elderly population, particularly in Latin America and Asia, and aging-related problems are anticipated to be discussed more seriously [12]. Compared to the developed countries in recent years, it has been found that the ratio of elderly population in developing countries is increasing more rapidly [13].

When the literature on loneliness is examined, it is found that loneliness is experienced commonly in many parts of the society, but it is a greater problem especially for older people $[14,15,16,17]$. According to the loneliness and age report, loneliness feeling is seen at the rate of $80 \%$ in those aged 65 years and over and $40 \%$ in those under 18 years old and younger, this rate gradually decreases in the middle-adulthood, but it increases again at the age of 65 and over. That is, the period when the level of loneliness is seen the most common is the ages of $\geq 70$ years and older $[15,18,19]$. The percentage of loneliness significantly increases after the age of $75[20,21]$. Investigation of social isolation and loneliness to improve the health and quality of life of older people has become an increasingly recognized topic and health strategy on the international scene $[12,22]$.

As in the whole world, the elderly population in Turkey increases with a higher rate than the population in other age groups. The elderly population rate is estimated to rise from $7.7 \%$ in 2013 to $10.2 \%$ in $2023,20.8 \%$ in 2050 and $27.7 \%$ in 2075 according to population projections. According to the population projections, it is estimated that Turkey's elderly population rate will rise to $10.2 \%$ in 2023 and will be among the countries with "very old" populations [41]. It is thought that the 21. century will be the old century in Turkey, in line with the expectations of the whole world. In Turkey, individuals have started to spend much longer years in old age and the needs of older individuals specific to this period have come to the fore [42]. Thus, as in the whole world, the need for counseling and guidance services for the elderly has increased in Turkey.

Several scale adaptation studies have been conducted to determine the loneliness levels of people in Turkey. One 
of them is the UCLA Loneliness Scale, which was first adapted to Turkey and is widely used. Adaptation work on university students has been made by Demir [43]. Another scale is the child Loneliness Scale [44], which was adapted to measure the level of loneliness of children between the ages of 9 and 14. Another adaptation work is the scale of loneliness at work performed by Doğan, Çetin and Sungur [45]. This scale is intended to measure loneliness in business life. The literature review did not find a measurement tool to measure the loneliness of elderly people in Turkey.

Loneliness Scale, which is widely used in related research to measure the loneliness levels of adults and the elderly, was developed by the original Gierveld and Kamphuis [46], revised in 1999 and 2006 [47,23] is a measuring tool. The scale is one of the three most widely used tools for the measurement of loneliness and two tools for the measurement of loneliness levels of adults and the elderly [17, 24], developed with a particularly theoretical background, to provide valid and reliable evidence from a psychometric standpoint. Loneliness Scale is a reliable and valid measurement tool used in many international researches adapted to different cultures[48, 49, 50, 20, 51].

Turkish adaptation study of Akgül and Yeşilyaprak [26] made by scale; the loneliness of the elderly for the evaluation of new research will encourage the development of the field type and thus will make a significant contribution to the international literature the results of research that conducted to give the opportunity to compare the results with similar studies in this regard in terms of the stimulus is intended to create a source of comparative and intercultural studies. In line with this; in this study, the results of The Loneliness Scale for the elderly, which was adapted to Turkish culture to be used in determining the loneliness level of the elderly, were compared with Artificial Neural Networks and multivariate regression analysis and it was aimed to produce new results.

\section{Material and Methods}

\subsection{Expert System Development Process}

The design of the Expert System consists of three stages (Fig. 1).

- Collection and arrangement of survey data

- Developing the model by using ANN and MLR methods by determining training and test data

- Reporting performance results using statistical analysis

When each stage was analyzed separately, the data collected by the questionnaire in the first stage were taken and the attributes were determined. In addition, the data were subjected to normalization (in the range of $0-1$ ) to prevent the peak values of the data from adversely affecting the predictive performance. In this study, "Personal Information Form" and "Loneliness
Scale for Elderly" were applied to the sample to collect data. The scale was administered by interviewers using face-to-face interview technique. This scale is an assessment instrument developed to measure the feeling of loneliness [23]. It is an assessment instrument widely used in many countries and intercultural researches. While it is mostly used in the studies conducted in Netherlands and the United States of America, it is also used in studies conducted in European countries $[24,25]$. Adaptation of the scale into the Turkish culture was carried out by Akgul and Yesilyaprak [26]. In the second stage, models were developed using ANN and MLR techniques. During the development of the model with ANN, the number of layers, the number of neurons in each layer, learning algorithms and activation functions were used with various variations. In the final stage, the developed models are fed with test data and according to the performance criteria, the highest performance model that predicts the SL and EL values was determined.

\subsection{Study Group and Selected Variables}

The population of the study consisted of individuals aged 65 years and over living in the city center, districts, villages and towns of Kayseri province in 2014. The sample, on the other hand, consisted of 809 people who were voluntary to participate in the study. The demographic characteristics of the sample group of 809 people were as follows: $52.5 \%$ of the elderly people were female, and $47.5 \%$ were male; $54.9 \%$ of the 809 elderly people were in the age group of 64-74 years; $29.5 \%$ were in the age range of $75-84$ years, and $15.6 \%$ were individuals aged 85 years and over. It was determined that $56.5 \%$ of the individuals in the sample group were literate and primary school graduates; $8.8 \%$ were secondary school graduates; $7.5 \%$ were high school graduates; $3.5 \%$ were university graduates; $0.9 \%$ had postgraduate education, and also $22.9 \%$ were illiterate. When the marital status of the individuals was examined, $46.6 \%$ were still married; spouses of $42.9 \%$ died; $6.2 \%$ were divorced; $2.2 \%$ never married, and $1.7 \%$ were living separately from their spouse. When the sample group was examined in terms of the place of residence, $45.9 \%$ were living at their own home together with their family, $19.8 \%$ were living with the family of their children; $18.3 \%$ were living alone at their own home, and $13.6 \%$ of them were living in facilities affiliated with the social service institution.

In this study, ten attributes as independent variables were selected on the collected data. We can mention about many factors that cause the sense of loneliness in elderly people. The feeling of loneliness in the elderly arises as a result of a single cause among these factors, sometimes multiple causes, at times the interaction of multiple causes with each other. In the study, it was aimed to examine the correlation between various independent variables and elders' loneliness levels which are the dependent variable. These variables were 
gender, age, educational level, marital status, number of children, employment/ working condition, whom they are living with, monthly income level, health status, and the place of residence $(G, A, E D L, M S, N C, W O C, W L, M I L$, HS, PR). These variables are thought to affect the elders' loneliness levels. Individuals live this period differently based on their individual characteristics, and it is a factor affecting the individual characteristics such as $G$, A, MS. Loneliness increases slowly and with age, the feeling of loneliness is more frequent and higher in women than in men at the same age. As a result of a meta-analysis of 149 studies conducted on women aged between 60 and 80 years in various countries, it was found that women felt more loneliness than men at the same age [27]. Loneliness levels were higher in widow men and women compared to the married ones and in those without children compared to those with the kids. Correlation between the loneliness feeling and the health status was also determined, and elders with poor health status were found to feel more alone [28]. Increasing number of studies has shown that loneliness is associated with a range of physical and psychological health problems in elderly individuals [19]. Other risk factors in the loneliness of elderly people are low economic status, low educational status, lack of supportive friendships, life fatigue, and lack of social networks $[24,29,30]$. The family is the most important institution for care, protection, support, sustaining the life, and meeting the needs of the elderly people. The existence of spouse in the old age period reduces the loneliness, difficulties of the old age are coped with together. However, the adult children take the place of the spouse when she/he is dead, and adult children are the most important support and social communication source for the elderly people [25]. The death of an old individual's spouse or friends creates a psychological depression on him/her. Not having anyone to replace the person who has passed away causes the feelings of loneliness and isolation in him/her [31].

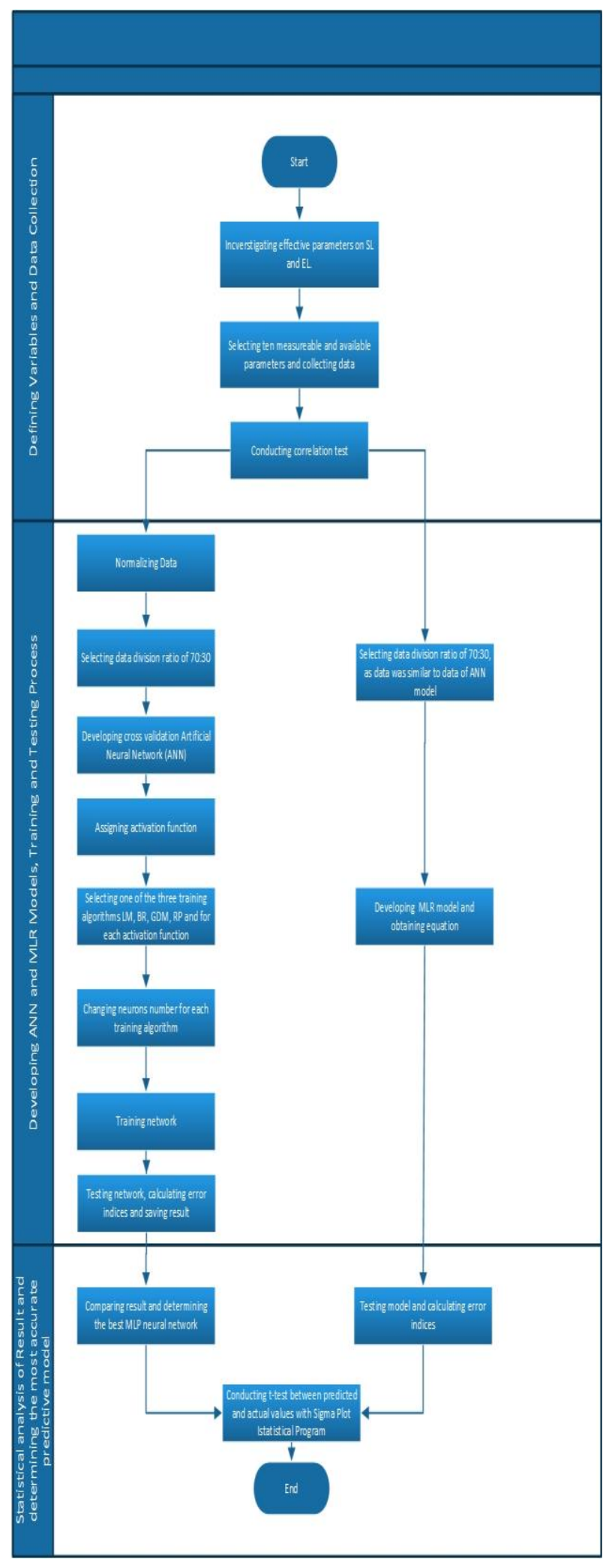

Figure 1. Flow process determined to predict SL and EL

[32]

Thus, ten relevant variables as input for this study $G, A$, EL, MS, NC, WOC, WL, MIL, HS, PR. Consequently, in this 
study, we used 809 research data. When Table 1 and Table 2 are examined respectively, The descriptive statistics of the data (Table 1) and the correlation (Table 2 ) among the ten attributes and SL, EL are indicated.

Table 1. Descriptive Statistics of All Research Data.

\begin{tabular}{|c|c|c|c|c|}
\hline Varıables & Mean & SD & Min & $\begin{array}{l}\text { Ma } \\
\mathbf{x}\end{array}$ \\
\hline G & 1,475 & 0,5 & 1 & 2 \\
\hline A & 1,607 & 0,742 & 1 & 3 \\
\hline EDL & 2,52 & 2,062 & 1 & 6 \\
\hline MS & 2,52 & 1,48 & 1 & 6 \\
\hline NC & 3,895 & 1,267 & 1 & 6 \\
\hline WOC & 2,517 & 0,589 & 1 & 4 \\
\hline WL & 2,11 & 1,259 & 1 & 6 \\
\hline MIL & 1,713 & 1,037 & 1 & 5 \\
\hline HS & 1,541 & 0,506 & 1 & 3 \\
\hline PR & 3,289 & 1,053 & 1 & 5 \\
\hline $\begin{array}{l}\text { Social } \\
\text { Loneliness }\end{array}$ & 3,778 & 3,217 & 0 & 10 \\
\hline $\begin{array}{l}\text { Emotional } \\
\text { Loneliness }\end{array}$ & 7,025 & 3,643 & 0 & 12 \\
\hline
\end{tabular}

Table 2. Calculated correlation coefficients between SL, EL and ten independent variables.

\begin{tabular}{lrr}
\hline & SL & EL \\
\hline G & $-0,0305$ & $-0,13$ \\
A & 0,344 & 0,261 \\
EDL & 0,153 & 0,0944 \\
MS & 0,31 & 0,295 \\
NC & $-0,102$ & $-0,0983$ \\
WOC & 0,0542 & 0,0945 \\
WL & 0,297 & 0,233 \\
MIL & $-0,0844$ & $-0,0374$ \\
HS & $-0,161$ & $-0,13$ \\
PR & $-0,176$ & $-0,103$ \\
\hline
\end{tabular}

\subsection{Model of ANN}

Feed-Forward Neural Network (FFNN) is one of the commonly used methods of ANN $[33,34]$.

In FFNN, there are basically three types of layers. The input layer is fed with data entering the ANN model [34]. This layer contains the number of nodes as independent variables. Each node in the hidden layer is fed to each node in the input layer. Each node in the hidden layer fed by the data processes the data and trains itself according to the desired output variables. This training is carried out by changing the weights between the layers. Each input data is multiplied by these weights and nodes in the hidden layer are fed together with values from all input layers to obtain a net input value. With this process, the effects of the inputs on the output can be adjusted [33, 35]. Eq. (1) shows the output $y_{j}$ of each node $\mathrm{j}$ [36].

$y_{j}=f\left(\sum_{i=1}^{m} W_{j i} X_{i}+b_{j}\right)$

$X_{i}$ is the output of the node of the previous layer. $W_{j i}$ is the weight of the connections between the two nodes. $b_{j}$ is the input value that is considered a node threshold. Afterwards, The results obtained from the activation function are sent to the output layer. The output layer is the layer in which the output values are shown, and the data sent to that layer is converted to the output by multiplying the weights of the connections with the previous layer and correlating with the linear activation function [ $33,35,37]$.

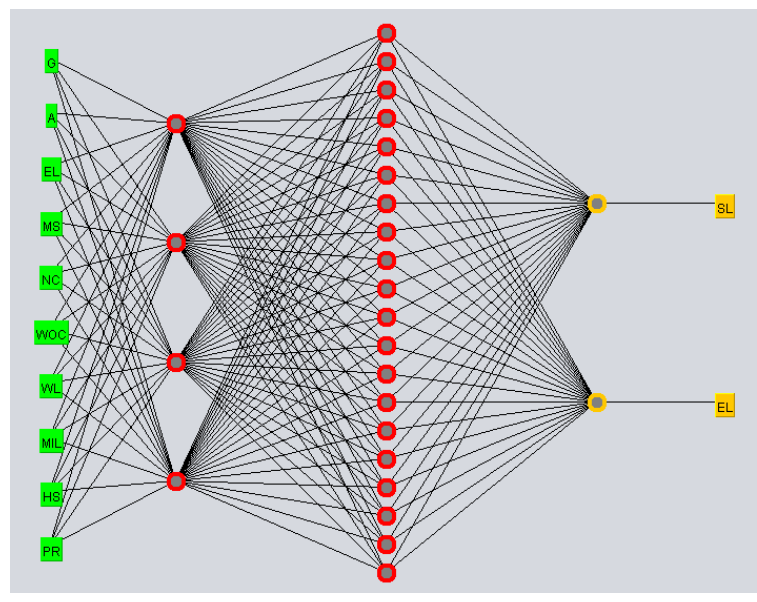

Figure 2. ANN Model.

In this study, ten attributes (G, A, EL, MS, NC, WOC, WL, MIL, HS, PR) and two target variables (SL and EL) were determined. Attributes and target variables are defined as input and output parameters to ANN model, respectively. Total data size consists of 809 lines. While many models with one hidden layer were developed during the development of the model, sufficient performance could not be obtained and as a result, experiments with two hidden layers were obtained and the highest performance was achieved. Similarly, various variations have been tried to determine the number of nodes in hidden layers to achieve better results depending on the complexity of the study.

Although theoretically many activation functions are used, the most commonly used activation functions are tansig, logsig and pure functions [32, 33, 35]. During the development of the model, we achieved better performance in estimating SL and EL by using tansig and logsig functions in hidden layers, purely linear and tansig functions in the output layer. 
During the training process of ANN, the weight values of the network are determined randomly (among -1 and 1 ) and these weight values are changed by using the training algorithm which will minimize the error rate between the original values and the predicted values. In the study, the network was trained 500 to 1000 times, and at each training stage, the network begins the training process with new initial weights to achieve global optimum value.

In the study, Levenberg-Marquardt (LM), Resilient back Propagation (RP), Bayesian Regulation (BR), Gradient Descent with Momentum (GDM) algorithms were used to train the network and all algorithms were compared based on performance criteria.

Normalization, one of the preprocessing methods, is done before the training process to speed up and facilitate the learning of the network [33]. In the normalization process, high peak values and other data are compressed to a certain numerical range to meet the requirements of the algorithm. Although there are many equations used in the normalization process, in this study, data conversion has been performed using Eq. 2 .

$x_{n}=0.8 x\left[\frac{x-x_{\min }}{x_{\max }-x_{\min }}\right]+0.1$

In this equation, $x$ defines the original data. $x_{n}$ is data that has been converted after normalization. $x_{\min }$ and $x_{\max }$ represent the minimum and maximum values of $x$ values, respectively.

In order to evaluate the performance of the developed models, they need to be tested on data they have never seen before. Therefore, the data were divided into 3 groups (training set, validation set, test set). The training set is used to train and develop the model. The validation set is used to stop the training process if certain constraints are identified during the training phase. The test set is used to evaluate the performance of the model $[35,36]$. In this study, the number of iterations tried to train the network was determined as 500 and 1000 . When the parameter, which is accepted as a validation error, reaches 6 repetitions, the training process is stopped. In the study, 809 data sets were divided into $70 \%, 15 \%$ and $15 \%$ proportions as training, validate and test, respectively. Proportional distributions were made by random selection of data rather than sequentially. The data were trained with learning algorithms and then their performance was compared using test data.

\subsection{Model of MLR}

MLR is a statistical method that uses two or more independent variables to predict a dependent variable. The aim of MLR is to create a model by using the relationship between dependent variable and independent variables. MLR was first presented by Francis Galton in the 19th century [38, 39].
Formally, the model for Multivariate regression, given $\mathrm{n}$ observations, is equations (3)

$y_{i}=\beta_{0}+\beta_{1} x_{i 1}+\beta_{2} x_{i 2}+\cdots+\beta_{p} x_{i p}+\varepsilon$

for $\mathrm{i}=1,2, \ldots \mathrm{n}$.

$y_{i}=$ dependent variable

$x_{i}=$ independent variable

$\beta_{p}=$ slope coefficients for independent variable

$\beta_{0}=$ constant term

$\mathcal{E}=$ residuals (error term)

In this study, ten independent variables $G, A, E L, M S, N C$, WOC, WL, MIL, HS, PR, for 809 data were used. The volumes of SL and EL were determined as the dependent variable. 809 data were employed in MLR model. Then $70 \%$ of all data (567 data) were used to obtain MLR equivalence. Then, The remaining 30\% of data (242 data) was used for prediction.

\subsection{The Method Used to Evaluate The Prediction Performance}

There are several methods to evaluate the performance of the developed model. In this study, in order to analyze the difference between the original values and the predicted values, we calculated the Root Mean Absolute Error (RMSE) with the following formula(Eq. 4). This value is close to zero indicates that the model's ability to predict is high.

RMSE $=\sqrt{\frac{\sum_{i=1}^{n}\left(P_{s i m}^{i}-P_{o b s}^{i}\right)^{2}}{n}}$

\section{Results and Discussion \\ 3.1. Evaluate Correlation Coefficient}

In this study, firstly, the linear relationship between independent variables (G, A, EL, MS, NC, WOC, WL, MIL, HS, PR) and dependent variables (SL and EL) was examined. One of the commonly used parameters for analyzing the linear relationship between variables is the correlation coefficient. The correlation coefficient is between -1 and 1 . The fact that these values are close to 1 indicates a positive linear relationship between the variables (one of them increases while the other increases or the process works the opposite way). The process is working exactly the opposite.). However, if the value is close to 0 , the linear relationship between the variables weakens. When the correlation coefficients are examined in this study, positive and negative coefficients are seen (Table 2). When we examine at the correlation coefficient between "AGE" and "SL", independent and dependent variables, it is seen that the highest linear relationship is between these two variables and is in the positive direction. This means that if the value of the "AGE" variable increases, the value of the "SL" variable will also increase or if one 
decreases, the other decreases. Examining the relationships between variables is an important element in developing the predictive capabilities of models. After this stage, MLR and ANN models were developed and their performances were examined.

\subsection{Analysis of ANN's Predictive Performance Of SL And EL's Volumes}

In this study, the developed ANN model is designed as a 4-layer with the experiments. These layers are designated as an input, two hidden layers and an output layer, and the number of neurons in the hidden layers is 4 and 20 (10-4-20-2). Fig. 2 shows ANN model.

. In the developed model, three activation functions (tangis, logsig, purelin) and four learning algorithms (GDM, RP, LM, BR) were used. RMSE was calculated to determine the performance of the model. According to Table 3, the model developed using the GDM algorithm has the highest estimation capability. The data were divided into three groups. The model was trained with training data, the stopping point was determined during the training with validation data, and the estimation performance of the network was measured with test data.

The distribution graph is used as a useful tool to show the relationship between dependent and independent variables [40]. If the distribution between the two variables is indicated by a straight line, it shows that the relationship between these two variables is high. The relationship among the predicted values obtained with the ANN model developed and the original values is shown in Fig. 3 and Fig. 4. When these graphs are analyzed, it is seen that the correlation coefficients between original and predicted SL and EL values are high. When we examine t-test results (Table 4 and Table 5) which is one of the statistical comparison methods, it is seen that $\mathrm{p}$ value is greater than 0.05 . A $\mathrm{p}$ value greater than 0.05 indicates no statistically significant difference between the original and predicted values.
Table 3. Performance of ANN models in training and testing situations

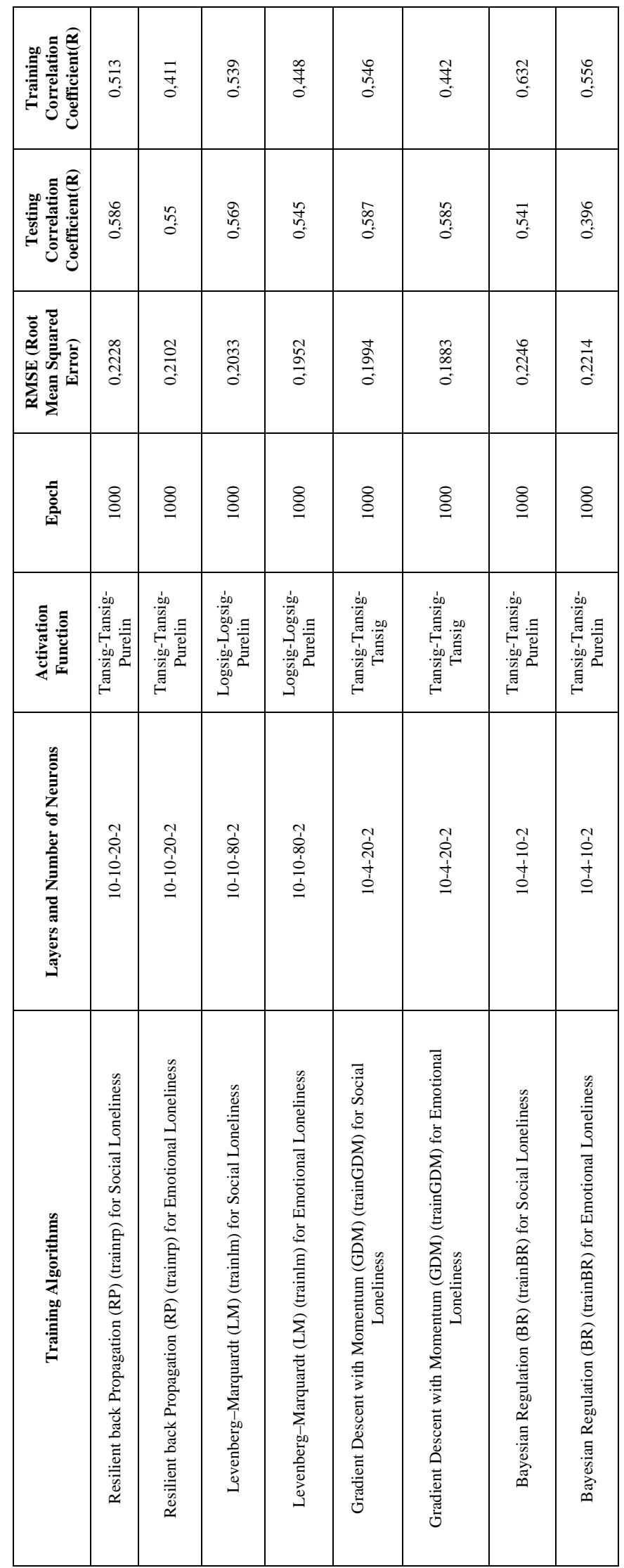




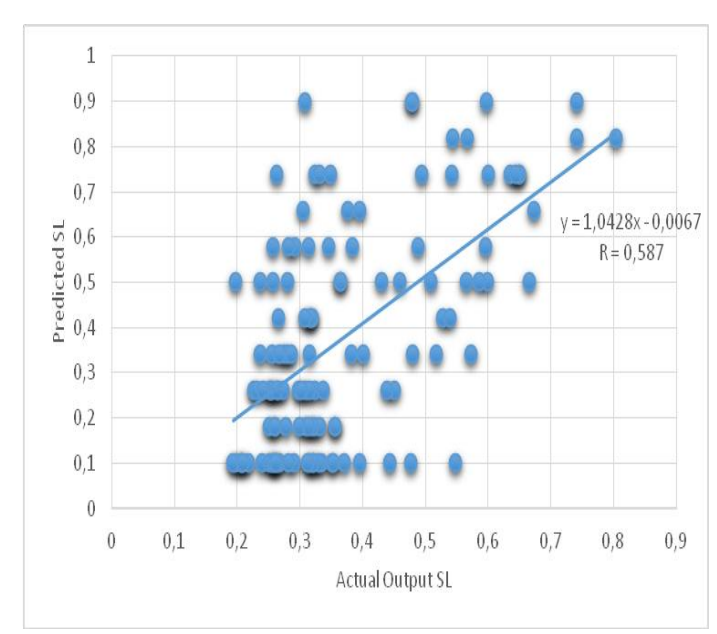

Figure 3. Scatter plot among original SL and ANN predicted SL.

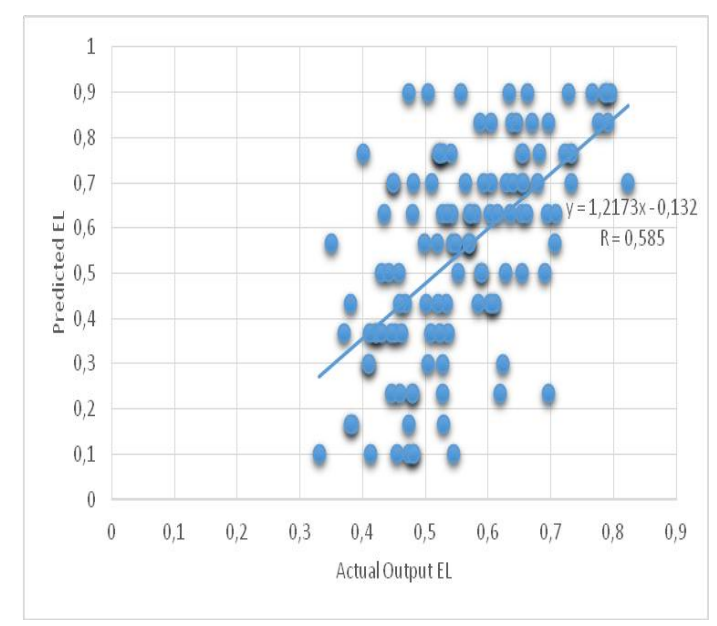

Figure 4. Scatter plot among original EL and ANN predicted EL

Table 4. Demonstration of the relationship between the original SL and ANN predicted SL by statistical t-test

\begin{tabular}{lrr}
\hline Group & $\begin{array}{r}\text { Predicted } \\
\text { SL Values }\end{array}$ & $\begin{array}{c}\text { Original } \\
\text { SL } \\
\text { Values }\end{array}$ \\
\hline $\mathrm{N}$ & 121 & 121 \\
Missing & 0 & 0 \\
Mean & 3,397 & 3,512 \\
Std Dev & 1,739 & 3,088 \\
SEM & 0,158 & 0,281 \\
P Value & 0,721 & \\
\hline
\end{tabular}

Table 5. Demonstration of the relationship between the original EL and ANN predicted EL by statistical t-test

\begin{tabular}{|c|c|c|}
\hline $\begin{array}{l}\text { Group } \\
\text { Name }\end{array}$ & $\begin{array}{l}\text { Predicted } \\
\text { EL } \\
\text { Values }\end{array}$ & $\begin{array}{l}\text { Original } \\
\text { EL Values }\end{array}$ \\
\hline $\mathrm{N}$ & 121 & 121 \\
\hline Missing & 0 & 0 \\
\hline Mean & 6,912 & 6,760 \\
\hline Std Dev & 1,664 & 3,464 \\
\hline SEM & 0,151 & 0,315 \\
\hline P Value & 0,664 & \\
\hline
\end{tabular}

The comparison among the predicted values obtained with the ANN model developed and the original values is shown in Fig. 5 and Fig. 6.

Looking at the overall, ANN can predict SL and EL sufficiently, and this field can be considered as an expert system.

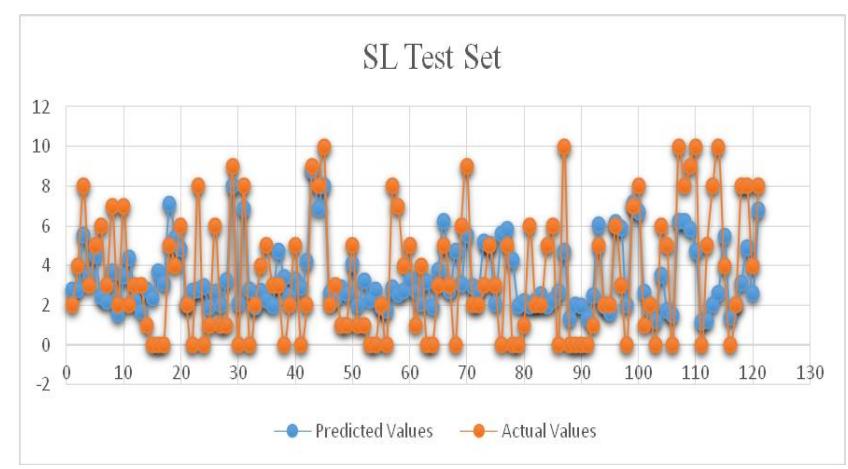

Figure 5. Original SL included in the test set and predicted SL obtained by GDM algorithm for ANN

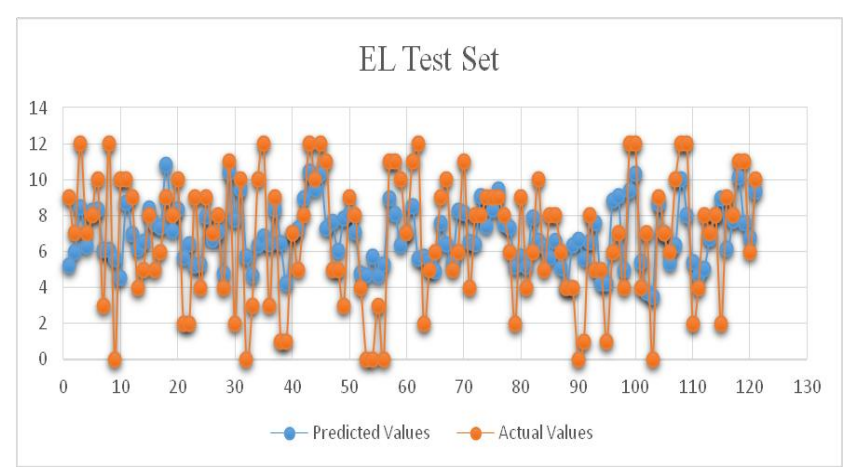

Figure 6. Original EL included in the test set and predicted EL obtained by GDM algorithm for ANN

\subsection{Analysis MLR's Predictive Performance Of SL And EL's Volumes}

During the development of the MLR model, which is one of the statistical estimation methods, firstly all data 
were divided into $70 \%$ and $30 \%$ slices. Statistical coefficients were calculated with the data in the $70 \%$ slice. Thus, The statistical significance of the coefficients of each independent variable and the model itself were examined in the MLR model to be created with the $70 \%$ data allocated.

When the statistical significance of the coefficients of the independent variables of the MLR model developed for SL and EL, respectively, in Tables 6 and 8, it is seen that the coefficients of some variables are statistically insignificant $(\mathrm{P}>0.05)$ and the coefficients of some variables are significant $(\mathrm{P}<0.05)$. However, when the MLR models developed for SL and EL are examined in Tables 7 and 9, respectively, it is seen that the MLR models developed for both dependent variables are significant since the $\mathrm{P}$ value is less than $0.05(\mathrm{P}<0.05)$.

Table 6. Representation of statistical significance of coefficients for independent variables for SL.

\begin{tabular}{cc}
\hline \multicolumn{3}{c}{ Coefficients $^{\mathbf{a}}$} \\
\hline (Constant) & Sig \\
G & 0,000 \\
A & 0,271 \\
EDL & 0,000 \\
MS & 0,518 \\
NC & 0,032 \\
WOC & 0,012 \\
WL & 0,922 \\
MIL & 0,027 \\
HS & 0,001 \\
PR & 0,015 \\
\hline
\end{tabular}

a. Dependent Variable: SL

Table 7. Representation of statistical significance of the MLR Model developed for SL.

\begin{tabular}{cccccr}
\hline & $\begin{array}{c}\text { Sum of } \\
\text { Square } \\
\text { s }\end{array}$ & df & $\begin{array}{c}\text { Mean } \\
\text { Squar } \\
\text { e }\end{array}$ & F & Sig. \\
\hline $\begin{array}{c}\text { Regressio } \\
\mathbf{n}\end{array}$ & 1300,84 & 10 & 130,08 & 17,36 &, 000 \\
Residual & 4164,09 & 556 & 7,48 & & \\
Total & 5464,93 & 566 & & & \\
\hline
\end{tabular}

\footnotetext{
a. Dependent Variable: SL

b. Predictors: (Constant), PR, HS, WL, WOC, NC, EDL, MIL, G, A, MS
}

Table 8. Representation of statistical significance of coefficients for independent variables for EL.

\begin{tabular}{cc}
\hline \multicolumn{3}{c}{ Coefficients $^{\mathbf{a}}$} \\
\hline (Constant) & Sig \\
G & 0,000 \\
A & 0,566 \\
EDL & 0,000 \\
MS & 0,741 \\
NC & 0,014 \\
WOC & 0,001 \\
WL & 0,051 \\
MIL & 0,034 \\
HS & 0,278 \\
PR & 0,024 \\
\hline
\end{tabular}

a. Dependent Variable: EL

Table 9. Representation of statistical significance of the MLR Model developed for SL.

\begin{tabular}{cccccc}
\hline & $\begin{array}{c}\text { Sum of } \\
\text { Squares }\end{array}$ & df & $\begin{array}{c}\text { Mean } \\
\text { Square }\end{array}$ & F & Sig. \\
\hline Regression & 1190,04 & 10 & 119,00 & 10,93 &, $000^{\mathrm{b}}$ \\
Residual & 6051,22 & 556 & 10,88 & & \\
Total & 7241,27 & 566 & & & \\
\hline
\end{tabular}

a. Dependent Variable: EL

b. Predictors: (Constant), PR, HS, WL, WOC, NC, EDL, MIL, G, A, MS

Thus, the following formulas showing the relationship between dependent and independent variables were obtained.

$S L=0,516+(0,0291 * G)+(0,199 * A)+(0,0209 * E D L)+$ $(0,115 * M S)-(0,127 * N C)-(0,00414 * W O C)+(0,155 *$ $W L)-(0,184 * M I L)-(0,113 * H S)-(0,251 * P R)$

$E L=0,614-(0,0152 * G)+(0,134 * A)+(0,0108 * E D L)+$ $(0,131 * M S)-(0,170 * N C)+(0,0829 * W O C)+(0,149 *$ $W L)-(0,0587 * M I L)-(0,106 * H S)-(0,128 * P R)$

The $30 \%$ of all data is presented as input to the developed MLR model and the predicted values were obtained as outputs. The error and correlation coefficients between the predicted values and the original values were 0.35538 (RMSE) and 0.0819 (R) for 
SL for SL and EL, respectively; 0.3837 (RMSE) and 0.0238 (R) for EL.

When we examine t-test results (Table 10 and Table 11) which is one of the statistical comparison methods, it is seen that $p$ value is greater than 0.05 . A $p$ value greater than 0.05 indicates no statistically significant difference between the original and predicted values.

Table 10. Demonstration of the relationship among the original SL and MLR predicted SL by statistical t-test

\begin{tabular}{lrr}
\hline $\begin{array}{l}\text { Group } \\
\text { Name }\end{array}$ & $\begin{array}{l}\text { Predicted } \\
\text { SL Values }\end{array}$ & $\begin{array}{l}\text { Original } \\
\text { SL Values }\end{array}$ \\
\hline $\mathrm{N}$ & 242 & 242 \\
Missing & 0 & 0 \\
Mean & 5,089 & 4,339 \\
Std Dev & 2,974 & 3,400 \\
SEM & 0,191 & 0,219 \\
P Value & 0,010 & \\
\hline
\end{tabular}

Table 11. Demonstration of the relationship among the original EL and MLR predicted EL by statistical t-test

\begin{tabular}{lrr}
\hline $\begin{array}{l}\text { Group } \\
\text { Name }\end{array}$ & $\begin{array}{r}\text { Predicted } \\
\text { SL Values }\end{array}$ & $\begin{array}{c}\text { Original } \\
\text { SL } \\
\text { Values }\end{array}$ \\
\hline $\mathrm{N}$ & 242 & 242 \\
Missing & 0 & 0 \\
Mean & 9,760 & 6,847 \\
Std Dev & 3,308 & 3,794 \\
SEM & 0,213 & 0,244
\end{tabular}

P Value $\quad<0,001$

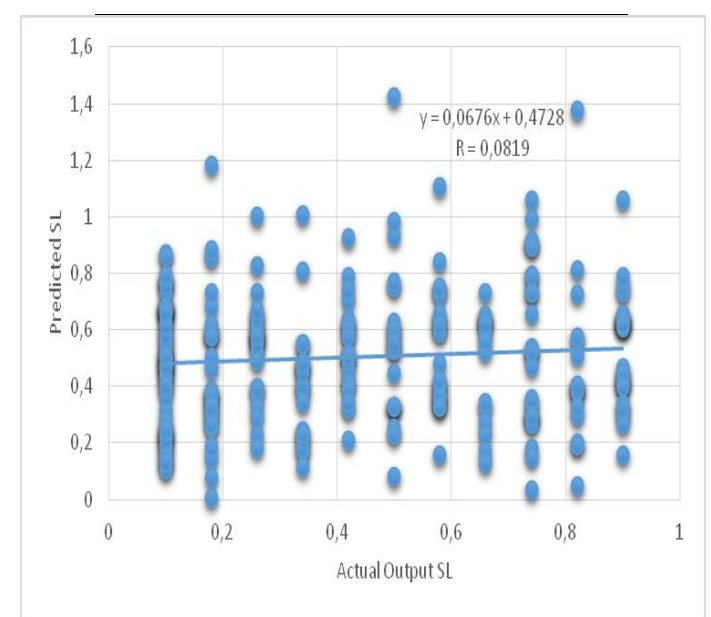

Figure 7. Scatter plot among original SL and MLR predicted SL

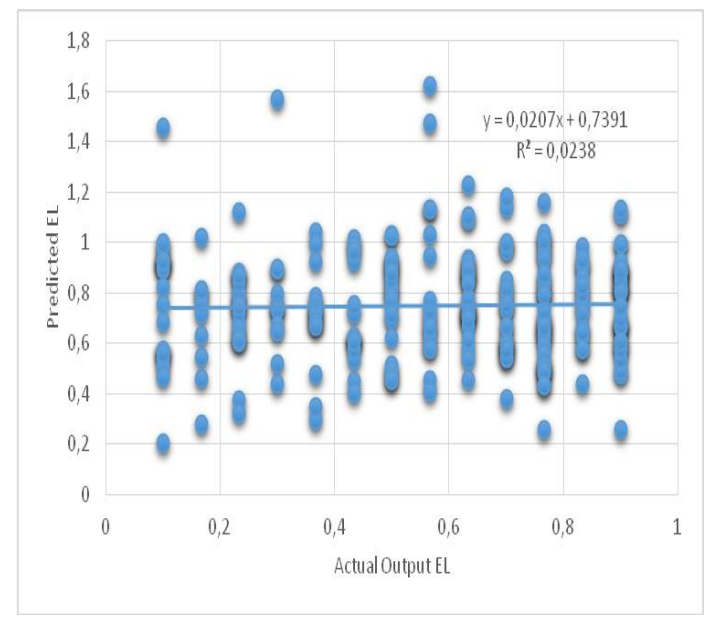

Figure 8. Scatter plot among original EL and ANN predicted EL

The relationship among the predicted values obtained with the MLR model developed and the original values is shown in Fig. 7 and Fig. 8. The comparison among the predicted values obtained with the ANN model developed and the original values is shown in Fig. 9 and Fig. 10.

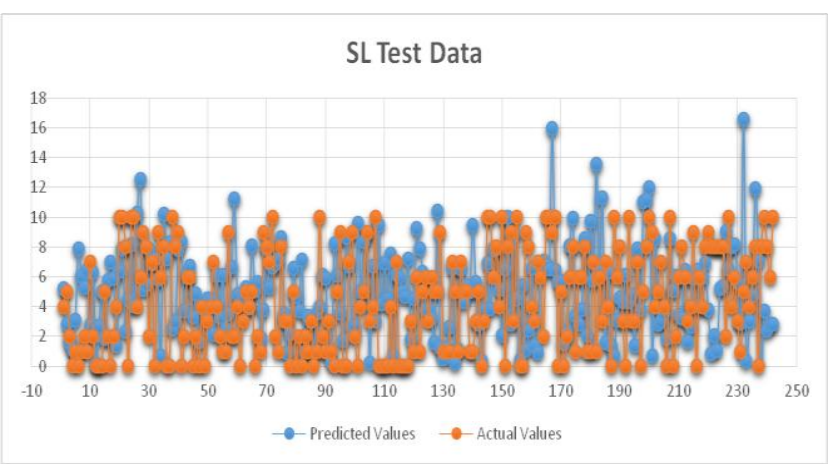

Figure 9. Original SL included in the test set and predicted SL obtained by MLR

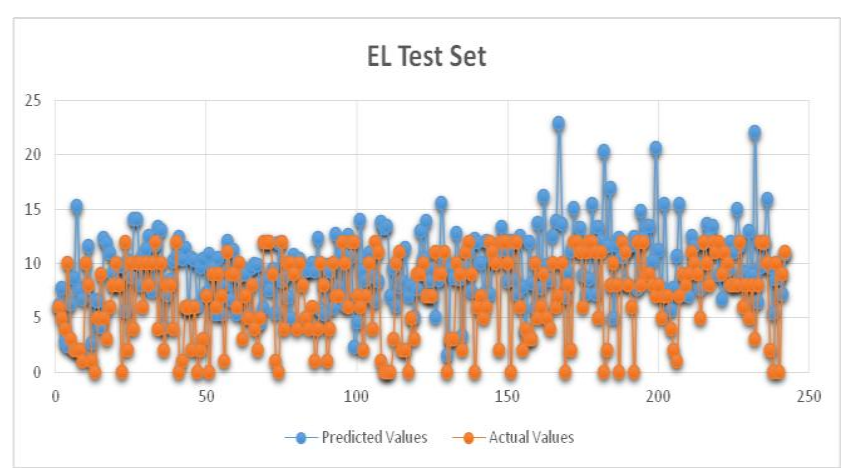

Figure 10. Original EL included in the test set and predicted EL obtained by MLR

When the statistical results (Table 10 - 12) of the developed MLR model are examined, it is seen that 
there is a significant difference between the original values and the predicted values $(\mathrm{p}<0.05)$. Furthermore, when the correlation coefficients seen in the graphical results (Fig. 7, Fig. 9 for SL and Fig. 8, Fig. 10 for EL) are examined, it proves that the MLR model does not have sufficient predictive performance.

\subsection{Comparison Of Predicting Capabilities Of MLR And ANN Models}

When Table 8 is examined for the performance of MLR and ANN (10-4-20-2, Tansig-Tansig- Tansig, GDM) models, RMSE values are 0. 1994 for SL and 0,1883 for EL When ANN model is checked, and RMSE values are 0,355387 for SL and 0,383703 for EL When MLR model is verified. Likewise, when the R-value for ANN is examined, it is 0,587 for SL and 0,585 for EL, when the $\mathrm{R}$-value for MLR is reviewed 0,0819 for SL and 0,0238 for EL. This puts forward that ANN has better predictability of SL and EL than MLR.

Table 12. Performance measurements for predictive capabilities of MLR and ANN model

\begin{tabular}{lcc}
\hline Models & RMSE & R \\
\hline $\begin{array}{l}\text { Gradient Descent } \\
\text { with Momentum } \\
\text { (GDM) (trainGDM) } \\
\text { for Social }\end{array}$ & 0,1994 & 0,587 \\
$\begin{array}{l}\text { Loneliness } \\
\text { Gradient Descent } \\
\text { with Momentum } \\
\text { (GDM) (trainGDM) } \\
\text { for Emotional }\end{array}$ & 0,1883 & 0,585 \\
$\begin{array}{l}\text { Loneliness } \\
\text { MLR for Social }\end{array}$ & & \\
Loneliness & 0,355387 & 0,0819 \\
$\begin{array}{l}\text { MLR for Emotional } \\
\text { Loneliness }\end{array}$ & 0,383703 & 0,0238 \\
\hline
\end{tabular}

\section{Conclusions}

In order for our lives to continue with quality, having information about the psychology of people and making quick interventions in line with their emotional needs is one of the important topics. According to our research, one of the uses that artificial intelligence will be developed and will bring many solutions in the future can be seen as a psychology field.

When the field of psychology is examined as an area where artificial intelligence can be used, the most important shortcomings are experienced in obtaining personal information. However, if annual, monthly or even daily information can be obtained from individuals, the psychological state of the person can be analyzed in real time with artificial intelligence and the support process related to the information obtained about the change in his psychological state can be provided in a more accurate time and in a more coordinated structure.

In this regard, to our best knowledge, our aim in this study, which is one of the most comprehensive researches in psychology is to predict the data that has never been seen with high accuracy by designing an expert system including models developed with ANN and MLR techniques. SL and EL values were predicted with the models developed in this direction and some results were obtained according to performance criteria. When the results were examined, it was seen that the expert system developed with ANN had higher estimation performance than the system developed with MLR.

Thus, according to the new survey data obtained in the future, accurate information about the psychological loneliness of people will be reached faster with the support of the developed expert system.

\section{References}

[1] Sullivan, H. S., (1953). Interpersonal Theory of Personality, New York: Norton Company Inc.

[2] Peplau, L. A. and Perlman, D., (1982). Perspective on Loneliness. In L. A. Peplau ve D. Perlman (Eds). Loneliness: A Sourcebook of Current Theory, Research and Therapy (13-46). New York: Wiley Interscience.

[3] De Jong Gierveld, J., (1998). "A Review Of Loneliness: Concept And Definitions, Determinants, And Consequences", Review in Clinical Gerontology, 8, 73-80.

[4] Geçtan, E., (2000). İnsan Olmak (20. Baskı), İstanbul: Remzi Kitapevi.

[5] Weiss, R., (1973). Loneliness: the Experience of Social and Emotional Loneliness, USA: MIT Press.

[6] Beal, C., (2006). "Loneliness In Older women: A Review Of The Literature", Issues in Mental Health Nursing, 27, 795-813. DOI: 10.1080/01612840600781196 http://www.tandfonline.com/doi/abs/1 $0.1080 / 01612840600781196$ (Access Date: 18.11.2014).

[7] Danış, M. Z., (2004). Yaşlıların Evde Bakım Gereksinimleri Ve Evde Bakıma İlişkin Düșünceleri: Başarılı Yaşlanma Ve Yaşlı Bakım Modelleri, Ankara: Türkiye Güçsüzler ve Kimsesizlere Yardım Vakfı yayını.

[8] Koşar, N., (1996). Sosyal Hizmetlerde Yaşlı Refahı Alanı, Ankara: Şafak Matbaacılı.

[9] WHO, (1998). The Uses of Epidemiology in The Study of The Elderly. (WHO, Technical Reports Series 706), Geneva: 8-9. (ErişimTarihi: 05.11.2014), http://www.who.int/whr/1998/en/

[10] Aiken, R. L., (1995). Aging: An Introduction to Gerontology (1th Edition), USA: Sage Publications.

[11] Maçkan, A. Ç., (2013). Yaşlılık Döneminde Problem Çözme Becerileri ve Esnekliğin Evlilik Uyumuna 
Etkisi, Yayımlanmamış Yüksek Lisans Tezi, Ankara Üniversitesi, Sağlık Bilimleri Enstitüsü, Ankara.

[12] WHO, (2002). World Health Organisation, Active Ageing A Policy Framework. WHO Noncommunicable Disease Prevention and Health Promotion Ageing and Life Course, Geneva. http://www.who.int/hpr/ageing/ActiveAgeingPolic yFrame.pdf (Access Date: 25.11.2015).

[13] Kalkınma Bakanlığı, (2014). Onuncu Kalkınma Planı, Yaşlanma, Özel İhtisas Komisyonu Raporu. Ankara.

[14] Revenson, T.A. (1986). Debunking The Myth Of Loneliness In Late Life, In E. Seidman and J. Rappaport (Eds.), Redefining Social Problems (115135), New York: Plenum Press.

[15] Stone, J., Evandrou, M. and Falkingham, J., (2013). "The Transition To Living Alone and Psychological Distress in Later Life", Age and Ageing, 42(3), 36672. doi: 10.1093/ageing/aft006. (Access Date: 25.11.2015).

http://www.ncbi.nlm.nih.gov/pmc/articles/PMC36 33366

[16] Tornstam, L., (2007). "Stereotypes of old people persist: A Swedish "Facts on aging quiz" in a 23-year comparative perspective", International Journal of Aging and Later Life, 2(1), 33-59. (Access Date: 15.02.2016)

http://www.ep.liu.se/ej/ijal/2007/v2/i1/a3/ijal07 v2i1a3.pdf

[17] Victor, C. R., Bowling, C. R., and Bond, J., (2002). Loneliness, Social Isolation and Living Alone in Later Life. Sheffield: ESRC.

[18] Eshbaugh, E., (2009). "The Role Of Friends İn Predicting Loneliness Among Older Women Living Alone", Journal of Gerontological Nursing, 35(5),1316.

http://www.ncbi.nlm.nih.gov/pubmed/19476188 (Access Date: 11.10.2014).

[19] Hawkley, L. C. and Cacioppo, J. T., (2010). "Loneliness Matters: A Theoretical and Empirical Review of Consequences and Mechanisms", Annals of Behavioral Medicine, 40(2), 218-227. DOI 10.1007/s12160-010-9210-8.

http://www.ncbi.nlm.nih.gov/pmc/articles/PMC38 74845/\#_ffn_sectitle (Access Date: 30.12.2014).

[20] Dykstra, P. A., (2009). "Older Adult Loneliness: Myths and Realities", European Journal of Ageing, 6, 91-100. DOI: 10.1007/s10433-009-0110-3. (Access Date: 25.11.2015).

[21] Schoenmakers, E. C, van Tilburg, T.G. and Fokkema, T., (2012). "Coping With Loneliness: What Do Older Adults Suggest?", Aging \& Mental Health, 16(3), 353360.

http://www.tandfonline.com/doi/abs/10.1080/13 607863.2011.630373 (Access Date: 25.11.2015).

[22] Cattan, M., White M., Bond J. and Learmouth A., (2005). "Preventing Social İsolation And Loneliness Among Older People: A Systematic Review Of Health Promotion Interventions", Ageing \& Society, 25, 41-67. DOI: 10.1017/S0144686X04002594. http://journals.cambridge.org (Access Date: 27.12.2017).
[23] De Jong Gierveld, J., and Van Tilburg, T. G., (1999). "Living arrangements of older adults in the Netherlands and Italy: Coresidence values and behaviour and their consequences for loneliness", Journal of Cross-Cultural Gerontology, 14, 1-24. http://link.springer.com/article/10.1023\%2FA\%3 A1006600825693 (Erişim Tarihi: 25.11.2017).

[24] Treacy, P., Butler M., Byrne A., Drennan J., Fealy G., Frazer K. and Irving K. (2004). Loneliness and Social Isolation Among Older Irish People, Dublin: School of Nursing and Midwifery University College, No:84.

[25] Victor, C. R, Scameler, S., and Bond, J., (2012). The Social World Order of Older People, New York: Springer Publishing Company, LLC. E-book ISBN: 978-0-8261 0800-5 Bilkent Üniversitesi.

[26] Akgül H. ve Yeşilyaprak B., (2015). "Yaşlılar İçin Yalnızlık Ölçeği'nin Türk Kültürüne Uyarlaması: Geçerlilik ve Güvenirlik Çalışması", Yaşlı sorunları Araştırma Dergisi, 8(1), 34-45. http://dergipark.ulakbim.gov.tr/yasad/article/vie $\mathrm{w} / 5000119293 / 5000117646 \quad$ (Access Date: 27.12.2014).

[27] Pinquart, M. and Sorensen, S. (2001). "Influences on loneliness in older adults: A metaanalysis", Basic and Applied Social Psychology, 23, 245-267.

[28] Tufan, İ., (2003). Modernleşen Türkiye'de Yaşlılık ve Yaşlanmak. İstanbul: Anahtar Kitaplar.

[29] Gamble, N. (2011). A Joint Project of the Centre for Addiction and Mental Health Dalla Lana School of Public Health, The University of Toronto and Toronto Public Health, Kanada: 2010 Centre for Addiction and Mental Health.

[30] MacCourt, P. (2004). Seniors Mental Health Policy Lens: An Instrument for Developing Policy, Legislation, Programs and Services That Promote and Support the Mental Health of Older Adults. Vancouver: British Columbia Psychogeriatric Association. Available. www.seniorsmentalhealth.ca/PolicyLensENG_1706. pdf.

[31] Koç, M. (2002). "Gelişim Psikolojisi Açısından Yaşlılık Döneminde Ruhsal Gelişim”, Sosyal Bilimler Enstitüsü Dergisi, 12, 287-304.

[32] Azadi S., Karimi-Jashni A., (2016). Verifying the performance of the artificial neural network and multiple linear regression in predicting the mean seasonal municipal solid waste generation rate: $\mathrm{A}$ case study of Fars province, Iran. Waste Management , 48, 14-23.

[33] Wang, Y., Li, J., Gu, J., Zhou, Z., Wang, Z., (2015). "Artificial neural networks for infectious diarrhea prediction using meteorological factors in Shanghai (China)", Appl. Soft Comput, 35, 280-290.

[34] Azadi, S., Sepaskhah, A.R., (2011). Annual precipitation forecast for west, southwest, and south provinces of Iran using artificial neural networks. Theor. Appl. Climatol.

[35] Zhang, G., Patuwo, B.E., Hu, M.Y., (1998). Forecasting with artificial neural networks: state of the art. Int. J. Forecast. 14, 35-62. 
[36] Kocadağlı, O., (2015). “A novel hybrid learning algorithm for full Bayesian approach of artificial neural Networks", Appl. Soft Comput. 35, 52-65.

[37] Beale, M.H., Hagan, M.T., Demuth, M.H., (2010). Neural Network ToolboxTM 7 User's Guide. MathWorks Inc: Natick, MA.

[38] Jahandideh, S., Jahandideh, S., Asadabadi, E., Askarian, M., Movahedi, M.M., Hosseini, S., Jahandideh, M., (2009). "The use of artificial neural networks and multiple linear regression to predict rate of medical waste generation", J. Waste Manage. 29, 2874-2879.

[39] Shu, Y., Lam, N.S.N., (2011). "Spatial disaggregation of carbon dioxide emissions from road traffic based on multiple linear regression model", Atmos. Environ, 45, 634-640.

[40] Flott, L.W., (2012). "Using the scatter diagram tool to compare data, show relationship", Met. Finis, 110, 33-35.

[41] TÜİK, (2013). Türkiye İstatistik Kurumu, Istatistiklerle Yaşlılar, http://www.tuik.gov.tr (Erişim Tarihi: 27.01.2020).

[42] Siviș, R. ve Demir, A., (2004). "Küresl Yaşlanma ve Türkiye'de Yaşlılarda Psikolojik Danışma ve Rehberlik". Türk Psikolojik Danışma ve Rehberlik Dergisi, 3(21), 43-48. (Erişim Tarihi: 18.01.2020). http://dergipark.ulakbim.gov.tr/tpdrd/article/view /1058000146/1058000148

[43] Demir, A., (1989). "U.C.L.A. Yalnızlık Ölçeğinin Geçerlik ve Güvenirliği”. Psikoloji Dergisi, 7 (23), 1418.

[44] Kaya, A. (2005). “Çocuklar İçin Yalnızlık Ölçeği'nin Türkçe Formu'nun Geçerlik Ve Güvenirlik Çalıșması". Eğitim Araştırmaları Dergisi, 19, 220237.

[45] Doğan T., Çetin B. ve Sungur M. Z., (2009). "İş yaşamında yalnızlık ölçeği Türkçe formunun geçerlilik ve güvenilirlik çalışması". Anadolu Psikiyatri Dergisi, $10(6), 271-277$.

[46] De Jong Gierveld, J., and Kamphuis, F. H., (1985). "The Development of a Rasch-Type LonelinessScale". Applied Psychological Measurement, 9, 289299. http://apm.sagepub.com/content/9/3/289

[47] De Jong Gierveld, J., and Van Tilburg, T. G., (2006). "A 6-Item Scale for Overall, Emotional, and Social Loneliness: Confirmatory Tests on Survey Data". Research on Aging, 28 (5), 582-598. http://home.planet.nl/ gierv005/ResonAging.pdf (Erişim Tarihi: 25.01.2020).

[48] Greenfield, E. A. and Russell, D., (2011). "Identifying Living Arrangements That Heighten Risk for Loneliness in Later Life: Evidence From the U.S. National Social Life, Health, and Aging Project". Journal of Applied Gerontology, 30(4), 524534. Http://jag.sagepub.com/content/30/4/524 (Erişim Tarihi: 25.01.2020).

[49] Korporaal, M., Broese van Groenou M.I., van Tilburg T.G. (2008). "Effects of own and spousal disability on loneliness among older adults". Journal of Aging and Health, 20, 306-325.
[50] Van Tilburg, T.G., Havens, B. and De Jong Gierveld, J. (2004). Loneliness among older adults in the Netherlands, Italy and Canada: A multifaceted comparison. Canadian Journal on Aging, 23:169180.

[51] De Leeuw, E. D., (1992). Data Quality in Mail, Telephone and Face to Face Surveys. Phd Dissertation, Vrije Universiteit, Amsterdam. 